\title{
Inovação Tecnológica
}

\section{Industrial}

Pela observação do cenário industrial mundial se Adotar nova visão e
estratégias implica em
modificar "zonas de conforto"
da cultura da organização
industrial demandando
recursos e tempo consideráveis. percebe que divergência entre taxas de crescimento entre nações é diretamente relacionada à disposição do seu parque industrial para a prática da competição tecnológica. Tanto no enfoque geopolítico, quanto no produtivo, países ou indústrias que se mantém na liderança se caracterizam pelo processo de desenvolvimento tecnológico. Esse processo é o fruto do estreito relacionamento entre a pesquisa e o empreendedorismo, e em sintonia com a governança pública, em sua função de indutora.

Do relacionamento pesquisa-empreendedorismo surgem as inovações tecnológicas industriais que criam valor aos processos produtivos, mas geram incerteza contínua na proporção deste mesmo relacionamento. Conseqüentemente, tensão é gerada na cadeia de valor com tal força que promove o realinhamento de estratégias de negócio e de perfil do profissional na indústria. Essa tensão é, então, direcionadora para a formatação e gestão dos negócios que buscam ambos a sobrevivência e a competitividade pela reformulação da visão e da estratégia da organização.

Adotar nova visão e estratégias implica em modificar "zonas de conforto" da cultura da organização industrial demandando recursos e tempo consideráveis. Este processo organizacional é caracterizado pelo esforço no alinhamento dos ativos hodiernos da tecnologia, do conhecimento e da informação, orientados à competitividade. São necessários reformulação de processos e produtos e o aculturamento das pessoas, pois inovação permanente, diferenciação de produtos e aprendizagem são fundamentos da competitividade. Nesse cenário, as indústrias líderes entendem a complexidade

do processo da competitividade, a qual permeia o estudo, a formulação e a melhoria contínua das técnicas de gerenciais e de produção, necessariamente precedidos da agregação de capital intelectual à organização.

Forte oponente à competitividade proporcionada pela inovação tecnológica industrial são a incapacidade promovida por certa cultura organizacional em aceitar ativamente os resultados científicos como oportunidades de negócio. A indústria é vulnerável quando sua base tecnológica da indústria é composta tão simplesmente por técnicas tradicionais e pela dependência da absorção de tecnologia importada. Objetiva-se, então, tanto o fortalecimento da pesquisa como a principal atividade geradora de conhecimento, quanto o resultado tecnológico dessas pesquisas sendo incorporadas no processo produtivo.

Recorrendo à história do desenvolvimento tecnológico industrial se verifica uma sucessão hegemônica de centros empreendedores do conhecimento, como: Inglaterra, Alemanha e Estados Unidos. O fundamento 
para a densa geração e utilização do conhecimento se associa às condições favoráveis à prática da pesquisa pragmática e orientada ao progresso da tecnologia e, conseqüentemente, ao desenvolvimento econômico. Foca-se em mover se a fronteira do conhecimento para áreas de futuro econômico (e social) promissor, como nanotecnologia, biotecnologia e os novos materiais. Neste diapasão, estudiosos e historiadores denominam esta coma uma economia do conhecimento, em que inovação e qualificação são fatores críticos do sucesso.

Para o setor industrial são paradoxais as políticas de desenvolvimento que assumem o modelo da cadeia linear da inovação tecnológica, o qual propõe que a tecnologia é resultado natural da pesquisa científica massificada, não a pesquisa induzida aos propósitos da competitividade. Já um modelo liberal e pragmático propõe um conceito de inovação, enquanto produto tecnológico na forma de recurso para a competitividade, diretamente relacionado ao empreendedorismo, e enfoca a pesquisa como processo de desenvolvimento da tecnociência.

A busca pela sobrevivência e pelo crescimento industrial em médio e longo prazo desafia as indústrias a se aproximarem dasáreas dinâmicas do conhecimento, apesar do difícil exercício da mudança da cultura organizacional e visão. A dinâmica da inovação e da difusão de tecnologias determina comportamentos empresariais diferenciados que demandam capacidades para gestão da pesquisa e do desenvolvimento tecnológico, seja na própria indústria, seja pela parceria assumida ou induzida, pela governança pública, com centros geradores de conhecimento. Assim, constitui elemento fundamental para a sustentabilidade industrial a articulação entre produção de conhecimento, e, especificamente, em seu locus privilegiado - a universidade. Redes que articulam pesquisadores de universidades e profissionais das indústrias aprofundam as relações entre o desenvolvimento pragmático da tecnociência e, consequentemente, da inovação.

A abordagem do respeitado estudioso Henry Etzkowitz identifica o modelo da Hélice Tríplice a qual situa a dinâmica da inovação pertencente ao campo das relações entre universidade, indústria e governo (as três hélices). Consideram-se as influências de cada hélice sobre as demais e seu efeito recursivo. O modelo discute a gestão da propriedade intelectual, a comercialização da tecnologia, a titularidade de patentes acontecendo em parceria com as universidades, especialmente, por meio de empresas de base tecnológica. Essas empresas são criadas, em parceria com as indústrias, mas no seio das universidades, muitas vezes resultantes de processos de incubação, outras vezes de processos naturais de empreendedorismo Objetiva-se dar foco pragmático à pesquisa e seu produto, preservando seu core business da indústria e desonerando da necessidade de mudança de cultura na implantação de centro próprio de desenvolvimento, mas assegurando sua parte nos produtos de tecnociência gerados.

Da parte do poder público se toma o Bay Dole Act o qual regula e viabiliza a comercialização de tecnologias desenvolvidas com recursos públicos em universidades norteamericanas. Da mesma forma, no Brasil, tem-se a Lei da Inovação federal, a qual regula e oportuniza a colaboração e parceria entre as universidades com o setor industrial. Diversos estados aprovaram e outros trabalham em leis de inovação estaduais.

O modelo da Hélice Tríplice não é proposta, mas identificação. Identifica a organização, as práticas e os atores que levam o processo de inovação industrial mais próximo do sucesso e, conseqüentemente, à sobrevivência empresarial e ao crescimento industrial. Portanto, sugerese aqui sua busca por meio de programas de pesquisa cooperativa (redes de pesquisa) envolvendo: $(i)$ o setor do conhecimento tipicamente, mas não exclusivamente, acadêmico, como fonte de capital intelectual; (ii) o setor produtivo, em especial o industrial, como direcionador de necessidades e oportunidades por meio da contratação de parcerias; e (iii) a governança pública, como indutora da organização do sistema de pesquisa tecnocientífica.

\section{Leonardo Guerra de Rezende Guedes}

Presidente da Fundação de Amparo à Pesquisa do Estado de Goiás (FAPEG). 